\title{
Prevalence of Hepatitis C virus (HCV) and Hepatitis B Virus (HBV) Co-infection among Human Immunodeficiency Virus (HIV/AIDS)
}

Mohamed Abdel-Basset gumie, Saeed Abdel-Baki Gad, Ahmed Alaa-Eldin Abdelrahman Ahmed Elgayar

Department of Internal Medicine, Faculty of Medicine - Zagazig University

*Corresponding author: Ahmed Alaa-Eldin Abdelrahman Ahmed Elgayar, Mobile: (+20)01095448831,

E-Mail: dr.ahmalaa89@gmail.com

\begin{abstract}
Background: HIV, HBV and HCV are still major public health concerns. Infections with these viruses rank among ten leading causes of death attributable to infectious diseases. The variability in the prevalence of HIV/hepatitis coinfection worldwide is multifactorial, and depends on geographic regions, infections' risk factors and type of exposure. Objective: To investigate HBV and HCV prevalence in HIV patients.

Patients and Methods: This study was conducted on HIV infected, and AIDS patients attending Alexandria Fever Hospital during the period from August 2018 to July 2019, assuming prevalence of HCV in HIV patients is 15\% sample was calculated to be 141 patients using epi info version 7 program with test power $80 \%$, CI $95 \%$.

Results: The incidence of infection with hepatitis C virus was 45 patients (31.9\%), all the 45 tested positive for PCR for HCV RNA as HIV accelerated progression of the disease making it almost impossible for HCV spontaneous clearance. This percentage is much higher than that of ordinary people, and the incidence of hepatitis B infection is 9 patients (6.4\%). The Prevalence of co-infection between hepatitis $\mathrm{C}$ virus and HBV among immunodeficiency patients was $2.8 \%$, with the combined infection among the three viruses in only 4 patients out of 141 patients.

Conclusion: the results of the present work underline the importance of continued screening of HIV positive for HBV as well as HCV markers before initiation of highly active antiretroviral therapy (HAART) as this practice would guide correct choice of drug combination.
\end{abstract}

Keywords: HCV, HBV, HIV, AIDS

\section{INTRODUCTION}

Human immunodeficiency virus (HIV) is a lentivirus (a member of the retrovirus family) which targets the immune system, resulting in a defect in cellmediated immunity that is demonstrated by increased vulnerability to opportunistic infections and to certain rare cancers. The most progressive stage of HIV infection is acquired immunodeficiency syndrome (AIDS) ${ }^{(1)}$.

HIV infects vital cells in the human immune system such as helper $\mathrm{T}$ cells (specifically CD4+ $\mathrm{T}$ cells), macrophages, and dendritic cells. HIV infection leads to low levels of CD4+ T cells through three main mechanisms; first; direct viral killing of infected cells, second; increased rates of apoptosis in infected cells, third; elimination of infected CD4+ T cells by CD8 cytotoxic lymphocytes that recognize infected cells, when $\mathrm{CD} 4+\mathrm{T}$ cells numbers decline below a serious level, cell mediated immunity is lost, and the body becomes progressively vulnerable to opportunistic infection. Most untreated people infected with HIV-1 eventually develop AIDS (2).

Human immunodeficiency virus (HIV) and hepatitis $\mathrm{B}$ and $\mathrm{C}$ viruses (HBV and $\mathrm{HCV}$ ) are the three most common chronic viral infections documented world-wide. These viruses have similar ways of transmission, namely through blood and blood products, sharing of needles to inject drugs and sexual activity, enabling co-infection with these viruses is a common event ${ }^{(3)}$. Vertical transmission of hepatitis B virus $(\mathrm{HBV})$ from mother to a child is frequent while rare in case of $\mathrm{HCV}^{(4)}$.
HBV and HCV co-infections in HIV positive individuals is of outmost importance due to the underlying consequences such as the hepatological complications associated with these viruses, which have been shown to decrease the life expectancy in the HIV-infected individuals ${ }^{(3)}$. As chronic infection can lead to scarring of the liver and ultimately to cirrhosis, which is generally apparent after many years. In some cases, those with cirrhosis will develop liver failure or other complications, including liver cancer or lifethreatening esophageal varices and gastric varices ${ }^{(5)}$. In coinfection, the presence of one virus influences the natural history of the other virus. HIV hastens the natural course of $\mathrm{HBV}$ and $\mathrm{HCV}$ infection and facilitates faster progression of liver disease to cirrhosis and hepatocellular carcinoma ${ }^{\left({ }^{6}\right.}$. Disease progression in HIV positive patients is nearly three times faster as compared to HIV negative patients ${ }^{(7)}$.

So, in Egypt nearly 2 - 3 million Egyptians are chronic carriers of $\mathrm{HBV}{ }^{(\mathbf{8})}$. And it was estimated that more than 6.8 million persons aged $15-59$ years had HCV antibodies, of which more than 4.5 million individuals had active $\mathrm{HCV}$ infection, having the highest HCV prevalence worldwide ${ }^{(9)}$. This unusually high incidence is attributable to the history of unsterile injection equipment use for mass treatment of the general population with parenteral anti schistosomal therapy (PAT) from the $1920 \mathrm{~s}$ to the $1980 \mathrm{~s}$, the prevalence of $\mathrm{HCV}$ increases with age with the highest rate reported in the age group older than 40 years ${ }^{(\mathbf{1 0})}$.

It is unclear how many people have HIV in the country. UNAIDS estimates more than 22,000 by end of $2018^{(11)}$. 


\section{AIM OF THE WORK}

\section{General objective}

To investigate HBV and HCV prevalence in HIV patients.

Specific objective

1- To detect main route of transmission of HIV.

2- To detect serologic markers of HBV in HIV patients.

3- To detect anti-HCV in HIV patients.

\section{SUBJECTS AND METHODS \\ Subjects:}

This study was conducted on HIV infected, and AIDS patients attending Alexandria Fever Hospital during the period from August 2018 to July 2019, assuming prevalence of HCV in HIV patients is $15 \%$ sample was calculated to be 141 patients using epi info version 7 program with test power $80 \%$, CI $95 \%$.

Inclusion criteria:

1. Confirmed HIV patient.

2. Male or female patient.

3. Age $>18$ years.

4. Patients on highly active antiretroviral therapy (HAART).

5. Any stage of HIV.

Exclusion criteria:

1. Any patient younger than 18 years old even if HIV positive.

2. Any patient who is $\mathrm{HCV}$ positive or $\mathrm{HBV}$ positive or both, but HIV negative.

Ethical consideration and written informed consent:

An approval of the study was obtained from Zagazig University Academic and Ethical Committee. Every patient signed an informed written consent for acceptance of the operation.

\section{Methods}

\section{Data collection methods:}

All of HIV patients were exploiting demographic assessment of clinical signs, opportunity infections, clinical stage classification, and screening $\mathrm{HBV}$ and $\mathrm{HCV}$. The following data were obtained from the patients' records: name, age, sex and modes of transmission, and confidentiality of records was considered.

All filing data from the institution were revised chronologically stressing on:

\section{1) Age of patient.}

2) Sex.

3) Onset of the disease.

4) Duration of the disease.

5) Complications.

6) Clinical assessment.

7) History:

- Family History.
- Sexual History.

- Drug Addiction.

\section{8) Investigations:}

A. Laboratory tests:

$>$ Routine normal lab: CBC, ESR, CRP.

$>$ Renal functions: Urea, creatinine.

$>$ Liver functions: AST, ALT, bilirubin total and direct, albumin.

$>$ Bleeding profile: INR, PT, PTT.

$>$ Tumor markers: AFP (Alpha feto protein)

\section{B. Radiological investigations:}

$>\mathrm{U} / \mathrm{s}$ abdomen and pelvis.

\section{Serological Hepatitis markers:}

> HBV/HIV coinfection was defined by a positive HBV surface antigen (HBsAg), and anti-HBc IgM to detect Occult HBV infection.

$>\mathrm{HCV} / \mathrm{HIV}$ coinfection was defined by a positive $\mathrm{HCV}$ antibody and Quantitative test PCR for HCV RNA.

\section{Statistical analysis}

Recorded data were analyzed using the statistical package for social sciences, version 20.0 (SPSS Inc., Chicago, Illinois, USA). Quantitative data were expressed as mean \pm standard deviation (SD). Qualitative data were expressed as frequency and percentage.

The following tests were done:

- Chi-square $\left(\mathrm{x}^{2}\right)$ test of significance was used in order to compare proportions between two qualitative parameters.

- The p-value was considered significant as the following:

- P-value $<0.05$ was considered significant.

- P-value <0.001 was considered as highly significant.

- P-value >0.05 was considered insignificant.

\section{RESULTS}

Table (1): Distribution of the studied cases according to demographic data

\begin{tabular}{|c|c|c|}
\hline & No. & $\%$ \\
\hline $\begin{array}{l}\text { Sex } \\
\text { Male } \\
\text { Female }\end{array}$ & $\begin{array}{c}111 \\
30\end{array}$ & $\begin{array}{l}78.7 \\
21.3\end{array}$ \\
\hline $\begin{array}{l}\text { Age (years) } \\
<30 \\
30-40 \\
>40\end{array}$ & $\begin{array}{l}41 \\
70 \\
30\end{array}$ & $\begin{array}{l}29.1 \\
49.6 \\
21.3\end{array}$ \\
\hline $\begin{array}{l}\text { Min. - Max. } \\
\text { Mean } \pm \text { SD. } \\
\text { Median }\end{array}$ & \multicolumn{2}{|c|}{$\begin{array}{c}21.0-69.0 \\
35.27 \pm 9.33\end{array}$} \\
\hline
\end{tabular}


Table (1): This table shows that this study included 111 males, and 30 females, also that most HIV patients were in the age group 30-40.

Table (2): Distribution of the studied cases according to some laboratory parameters $(n=141)$

\begin{tabular}{||l|c|c||}
\hline & Mean \pm SD. & Median \\
\hline Renal function & & \\
Urea & $47.53 \pm 6.39$ & 30.0 \\
Creatinine & $1.18 \pm 0.12$ & 0.90 \\
\hline Liver function & & \\
S. Albumin & $3.56 \pm 0.62$ & 3.50 \\
AST & $49.31 \pm 5.45$ & 33.0 \\
ALT & $39.88 \pm 9.37$ & 28.0 \\
\hline CBC & & \\
Hemoglobin & $11.40 \pm 2.92$ & 11.20 \\
Platelets $\left(10^{3}\right)$ & $228.5 \pm 9.52$ & 227.0 \\
WBCs & $7.11 \pm 1.34$ & 6.23 \\
\hline Total bilirubin & $2.18 \pm 0.74$ & 1.20 \\
\hline Direct bilirubin & $1.33 \pm 0.095$ & 0.70 \\
\hline AFP & $5.27 \pm 0.71$ & 5.0 \\
\hline GGT & $38.14 \pm 3.82$ & 32.0 \\
\hline
\end{tabular}

Table 2: shows the results of measuring renal functions and liver functions tests,

$\mathrm{CBC}$, total bilirubin, direct bilirubin, Alfa fetoprotein, and GGT.

Table (3): Distribution of the studied cases according to U/S abdomen

\begin{tabular}{|l|c|c|}
\hline U/S abdomen & No. & \% \\
\hline Normal & 93 & 66 \\
Abnormal & $\mathbf{4 8}$ & $\mathbf{3 4}$ \\
\hline Cirrhotic & 46 & 32.6 \\
HCC & 2 & 1.4 \\
\hline
\end{tabular}

Table (3) shows that among studies cases screened with ultrasound abdomen 93(66\%) were normal or showing minimal fibrosis while $46(32.6 \%)$ were cirrhotic and only $2(1.4 \%)$ had focal hepatic lesion (HCC).

Table (8):

Table (4): Descriptive of the studied cases according to coagulation profile $(n=141)$

\begin{tabular}{|l|l|c|}
\hline Coagulation profile & Mean \pm SD. & Median \\
\hline PT & $4.18 \pm 1.06$ & 4.0 \\
\hline PTT & $35.21 \pm 1.70$ & 35.0 \\
\hline INR & $1.18 \pm 0.17$ & 1.10 \\
\hline
\end{tabular}

Table (4) shows description of coagulation profile among studied cases.

Table (5): Distribution of the studied cases according to mode of transmission

\begin{tabular}{|c|c|c|}
\hline Mode of transmission & No. & $\%$ \\
\hline I V drug users & 31 & 22.0 \\
Sexual & 110 & 78.0 \\
\hline
\end{tabular}

Table (5) shows that sex was reported as the mode of transmission in 110 of the patients while only 31 was due to drug abuse.

Table (6): Comparison between $1^{\text {st }}$ and $2^{\text {nd }}$ round of ESR among studied cases $(n=141)$

\begin{tabular}{||ccccc|}
\hline ESR & $\mathbf{1}^{\text {st }}$ & $\mathbf{2}^{\text {nd }}$ & $\mathbf{Z}$ & $\mathbf{p}$ \\
\hline Mean \pm SD. & $23.26 \pm$ & $46.54 \pm$ & \\
& 6.33 & 7.20 & \\
Median & 20.0 & 50.0 & \\
\hline CRP & $\begin{array}{c}\text { Min. }- \\
\text { Max. }\end{array}$ & $\begin{array}{c}\text { Mean } \pm \\
\text { SD. }\end{array}$ & Median \\
\hline & $2.0-50.0$ & $\begin{array}{c}10.81 \pm \\
8.86\end{array}$ & 1.0 \\
\hline
\end{tabular}

Z: Wilcoxon signed ranks test

Statistically significant

Table (6) shows that among studied cases screened with ESR, the first round was significantly lower than the second round.

Table (7): Relation between mode of transmission and Gender

\begin{tabular}{|c|c|c|c|c|c|}
\hline \multirow{3}{*}{ Gender } & \multicolumn{4}{|c|}{ Mode of transmission } & \multirow{3}{*}{${ }^{\mathbf{F E}} \mathbf{p}$} \\
\hline & \multicolumn{2}{|c|}{$\begin{array}{c}\text { I V drug } \\
\text { users } \\
(\mathbf{n}=\mathbf{3 1})\end{array}$} & \multicolumn{2}{|c|}{$\begin{array}{r}\text { Sexual } \\
(n=110)\end{array}$} & \\
\hline & No. & $\%$ & No. & $\%$ & \\
\hline Male & 30 & 96.8 & 81 & 73.6 & $0.005^{*}$ \\
\hline Female & 1 & 3.2 & 29 & 26.4 & \\
\hline
\end{tabular}

- FE: Fisher Exact

: Statistically significant.

In table 7, modes of HIV transmission were compared in relation to gender. A statistical significance was found between gender and mode of HIV transmission $(\mathrm{P}$ value $=0.005)$.

Relation between mode of transmission and hepatitis $B$ and $C$ markers

\begin{tabular}{|l|c|c|c|c|l||}
\hline \multirow{2}{*}{} & \multicolumn{2}{|c|}{$\begin{array}{c}\text { Mode of transmission } \\
\text { I V drug } \\
\text { users } \\
(\mathbf{n = 3 1})\end{array}$} & \multicolumn{2}{|c|}{$\begin{array}{c}\text { Sexual } \\
(\mathbf{n}=\mathbf{1 1 0})\end{array}$} & \multirow{2}{*}{$\mathbf{p}$} \\
\cline { 2 - 5 } & No. & $\mathbf{\%}$ & No. & $\mathbf{\%}$ & \\
\hline HBsAg & & & & & \multirow{2}{*}{} \\
Negative & 30 & 96.8 & 102 & 92.7 & ${ }^{\mathrm{FE}_{\mathrm{p}}>}$ \\
Positive & 1 & 3.2 & 8 & 7.3 & 0.05 \\
\hline $\begin{array}{l}\text { HCV Ab } \\
\text { Negative }\end{array}$ & 23 & 74.2 & 73 & 66.4 & \\
Positive & 8 & 25.8 & 37 & 33.6 & $>0.05$ \\
\hline
\end{tabular}

\section{FE: Fisher Exact}

Table 8 shows the relation between mode of transmission of HIV with hepatitis B and C markers. 
Table (9): Relation between Gender and hepatitis B and $\mathrm{C}$ markers

\begin{tabular}{|c|c|c|c|c|c|}
\hline & \multicolumn{4}{|c|}{ Gender } & \multirow{3}{*}{$\mathbf{p}$} \\
\hline & \multicolumn{2}{|c|}{$\begin{array}{c}\text { Male } \\
(n=111)\end{array}$} & \multicolumn{2}{|c|}{$\begin{array}{c}\text { Female } \\
(\mathbf{n}=30)\end{array}$} & \\
\hline & No. & $\%$ & No. & $\%$ & \\
\hline HBsAg & & & & & \\
\hline Negative & 103 & 92.8 & 29 & 96.7 & $\mathrm{FE}_{\mathrm{p}}=$ \\
\hline Positive & 8 & 7.2 & 1 & 3.3 & $>0.05$ \\
\hline HCV Ab & & & & & \\
\hline Negative & 74 & 66.7 & 22 & 73.3 & $>05$ \\
\hline Positive & 37 & 33.3 & 8 & 26.7 & $>0.05$ \\
\hline
\end{tabular}

FE: Fisher Exact test

Table 9 shows the relation between gender with hepatitis B and C markers.

Table (10): Relation between age and hepatitis B and $\mathrm{C}$ markers

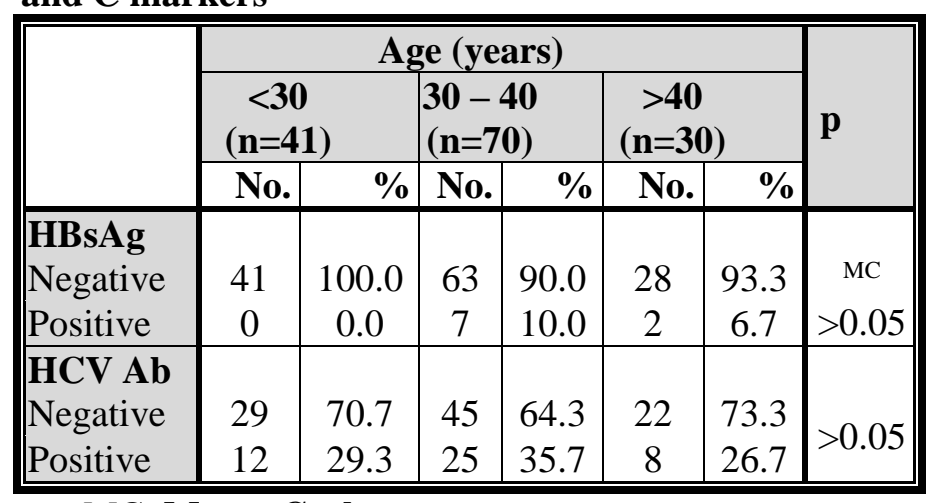

MC: Monte Carlo test

Table 10 shows the relation between age and hepatitis $\mathrm{B}$ and $\mathrm{C}$ markers.

\section{DISCUSSION}

This study was conducted on 141 HIV infected patients attending Alexandria Fever Hospital for diagnosis and follow up. Patients enrolled in the study were positive for anti-HIV antibody by EIA. They were screened for the following markers by ELISA technique: anti-HCV, HBsAG, anti $\mathrm{HBc}-\mathrm{IgM}$.

Among the HIV patients, $29.1 \%$ were less than 30 years old, $49.6 \%$ were from 30 up to 40 years old, and $21.3 \%$ were from older than 40 years old, the mean age was 33 years. In France, it was reported that $61 \%$ were more than 40 years and $39 \%$ less than 40 years ${ }^{(\mathbf{1 2})}$. While in Morocco the mean age of HIV patients was 40 years ${ }^{(13)}$. A mean age of 33.9 years reported in Kenya in $2013^{(\mathbf{1 4})}$ was close to that reported in present study. This may be due to increased sexuality in this age group which is the main reason of transmission of HIV.

As regards gender, $78.7 \%$ males and $21.3 \%$ females were included in the study. This finding was similar to that obtained previously in France in a study reporting $68 \%$ males and $32 \%$ females among studied HIV subjects ${ }^{(12)}$. Otherwise in Ethiopia in 2013, 30.5\% were males and $69.5 \%$ were females ${ }^{(\mathbf{1 5})}$.

As per mode of HIV transmission, the sexual route in this study was reported in $78 \%$ and drug abuse in $22 \%$. Similarly, in France and Morocco sexual transmission of HIV was the major route of transmission ${ }^{(\mathbf{1 2}, \mathbf{1 3})}$.

In the current study anti-HCV antibody was present in $45(31.9 \%)$ of HIV infected patients. It was significantly higher among males than females (33.3 vs $26.7 \%$ ). This observation was similar to previous studies conducted in Kenya (11.6\% vs 9.4\%) ${ }^{(\mathbf{1 4})}$, and in Morocco $(9.8 \%$ vs $1.1 \%),{ }^{(13)}$ and contrarily to other findings in Ethiopia where females were more coinfected $(5.6 \%)$ than males $(2.8 \%){ }^{(15)}$.

Egypt is a country of intermediate endemicity for HBV (2\%-7\%). A survey of HBsAg carriage reported a prevalence of $2 \%{ }^{(16)}$. In the present study only 9 (6.4\%) HIV patients were HBsAg carriers, in 2013, Rebbasni et al., reported 5.2\% HBsAg prevalence among HIV patients in Morocco which has also intermediate endemicity for $\mathrm{HBV}{ }^{(13)}$. In 2012 in Nigeria $28.4 \%$ of studied HIV patients were HBsAg carriers $^{(17)}$. This may be due to different prevalence of HBV as Nigeria is a high country of endemicity for HBV. Only 4 of these 9 patients $(2.8 \%)$ who tested positive for $\mathrm{HBsAg}$ were also positive for $\mathrm{HCV}$ antibodies. These findings were similar to those obtained previously in Kenya (1\%) (14), Nigeria $(1.5 \%)^{(\mathbf{1 7})}$ and Ethiopia (1.1\%) ${ }^{(15)}$ indicating a maintained low rate of these trio infections.

The HIV/HCV co-infection rate in this study was higher among male than female study subjects (33.3 vs $26.7 \%$ ). This observation may have been accounted to have multiple sex partners and also practice unprotected sex due to polygamous nature of their relationships or due to intravenous drug abuse among prisoners.

In the present study, the HIV/HCV co-infection was detected in $45(31.9 \%)$ of HIV positive patients while 4 (2.8\%) had triple infection of $\mathrm{HIV} / \mathrm{HBV} / \mathrm{HCV}$. In 2008, in Georgia, almost half (48.57\%) of HIV positive patients were found to be co-infected with $\mathrm{HCV}$ while $43.42 \%$ were co-infected with $\mathrm{HBV}$ and $5.14 \%$ had triple infection of $\mathrm{HIV} / \mathrm{HBV} / \mathrm{HCV}{ }^{(18)}$. These values are comparably higher than the values observed in this study. In 2005 in Australia, prevalence of HCV coinfection amongst HIV patients was $12.8 \%$ while HBV co-infection was $4.8 \%{ }^{(19)}$. In India, in 3 different studies, HCV co-infection / HBV co-infection amongst HIV patients were respectively [2.1\% / 6.4\%], [2.2\% / $9 \%$ and $[1.69 \% / 2.61 \%]^{(20,21)}$. In another study in New York City, $25 \%$ of HIV patients were co-infected with $\mathrm{HCV}$ while $4.47 \%$ were co-infected with $\mathrm{HBV}$ and about $1.6 \%$ had triple infection ${ }^{(22)}$.

Anti-HBc IgM indicating occult infection to HBV was detected in no one of the cases, the absence of anti$\mathrm{HBc} \operatorname{IgM}$ in the study participants indicates that their HBV infections were longstanding infections. Similar 
study performed in Ghana 2011, came out with the same conclusion as HIV accelerates progression of the disease into chronicity (chronic HBV infection) ${ }^{(23)}$.

\section{CONCLUSIONS}

Finally, the results of the present work underline the importance of continued screening of HIV positive for HBV as well as HCV markers before initiation of HAART as this practice would guide correct choice of drug combination. In general, patients with chronic hepatitis B and C should be screened for HCC every 6 to 12 months. Serum alpha-fetoprotein and an ultrasound of the liver should be performed. This recommendation is independent of apparent cirrhosis, as 10 to $30 \%$ of patients who develop HCC do not have pre-existing cirrhosis, this would in turn reduce morbidity and mortality from antiretroviral drug associated hepatotoxicity among these patients.

\section{RECOMMENDATIONS}

1) Routine screening of HIV infected patients for HBV and HCV markers prior to start of HAART therapy is mandatory.

2) Administration of HBV and HAV vaccine should be carried out for all non-vaccinated HIV patients.

3) HIV infected patients should be health educated as regards safe sex practice.

4) For patients presenting with anti-HBc as the sole HBV marker, PCR testing should be carried out to explore the presence of occult HBV.

\section{REFERENCES}

1. Weiss RA (1993): How does HIV cause AIDS? Science, 260(5112): 1273-9.

2. Cunningham A, Donaghy H, Harman A et al. (2010): Manipulation of dendritic cell function by viruses. Curr Opin Microbial., 13 (4): 524-9.

3. Rockstroh JK (2006): Influence of viral hepatitis on HIV infection. J Hepatol., 44:525-7.

4. Farooq T, Hameed A, Rehman $K$ et al. (2016): Antiretroviral agents: looking for the best possible chemotherapeutic options to conquer HIV. Crit Rev Eukaryot Gene Expr., 26(4):363-381.

5. Nusrat $S$ (2014): Cirrhosis and its complications: Evidence based treatment. WJG., 20(18):5442.

6. Mocroft A, Monforte A, Kirk O et al. (2003): Decline in AIDS and death rates in EuroSIDA study; an observational study. Lancet, 362:22-9.

7. Vallet-Pichard A, Pol S (2009): natural history and predictors of severity of chronic hepatitis $\mathrm{C}$ virus (HCV) co-infection. J Hepatol., 44:52834.

8. El-Zayadi AR( 2009 ): Evaluation of liver biopsy in Egyptian HBeAgnegative chronic hepatitis B patients at initial presentation: imply- cations for therapy. American Journal of Gastroenterology, 104: 906-911.

9. El - Zanaty F and Way A (2006): Egypt demographic and health service 2005. Cairo: Ministry of Health and
Population. https://www.dhsprogram.com/pubs/pdf/FR176/FR176.pd $\mathrm{f}$

10. Frank C, Mohamed MK, Strickland GT et al. (2000): The role of parentralantischistosomal therapy in the spread of hepatitis C virus in Egypt. Lancet, 355 (9207): 887-91.

11. UNAIDS (2018): Global HIV statistics. Available from: https://www.unaids.org/sites/default/files/ media_asset/ UNAIDS_FactSheet_en.pdf.

12. Larsen C, Pialoux G, Salmon D et al. (2008): Prevalence of hepatitis C and hepatitis B infection in the HIVinfected population of France, 2004. http://www.eurosurvillence.org/

ViewArticle.aspx?ArticleId=18888.

13. Rebbasni $K$, Ouladlahsen $A$, Bensghir A et al. (2013): Co-infections with hepatitis B and C viruses in human immunodeficiency irus-infected patients in Morocco. ClinMicrobiol Infect., 19(10):454-7.

14. Muriuki BM, Gicheru MM, Wachira D et al. (2013): Prevalence of hepatitis B and C viral co-infections among HIV-1 infected individuals in Nairobi, Kenya. BMC Research Notes, 6:363-9.

15. Wondimeneh Y, Alem M, Asfaw F et al. (2013): HBV and HCV seroprevalence and their correlation with CD4 cells and liver enzymes among HIV positive individuals at University of Gondar Teaching Hospital, Northwest Ethiopia. Virology Journal, 10:171-8.

16. World Health Organization (2007): Preventing HIV transmission with antiretrovirals. Bulletin of the WHO., 85: 281-900.

17. Balogun TM, Emmanuel S, Ojerinde EF (2012): HIV, Hepatitis B and C Viruses' coinfection among patients in a Nigerian tertiary hospital. Pan Afr Med J., 12:100-11.

18. Badridze N, Chkhartishvili N, Abutidze A et al. (2008): Prevalence of hepatitis B and C amng HIV positive patients in Georgia and its associated risk factors. Georgian Med News, (165):54-60.

19. Petoumenos K, Ringland C (2005): Australian HIV Observational Database. Antiretroviral treatment change among HIV, hepatitis B virus and hepatitis C virus cinfected patients in the Australian HIV Observational Database. HIV Med., 6(3): 155-63.

20. Padmapriyadarsini C, Chandrabose J, Victor L et al. (2006): Hepatitis $\mathrm{B}$ or hepatitis $\mathrm{C}$ c-infection in individuals infected with human immunodeficiency virus and effect of antituberculosis drugs on liver function. $\mathbf{J}$ Postgrad Med., 52(2):92-6.

21. SaraVanan S, Velu V, Kumarasamy N et al. (2007): Co-infection of hepatitis B and hepatitis C virus in HIVinfected patients in south India. World J Gastroenterol., 13(37): 5015-20.

22. Raizada A, Dwivedi S, Bhattacharya S (2011): Hepatitis B, hepatitis C and HIV co-infection at an antiretroviral center in Dlhi. Trop Doct., 41(3): 154-6.

23. Sagoe K, Agyei A, Ziga F et al. (2011): Prevalence and impact of hepatitis $\mathrm{B}$ and $\mathrm{C}$ virus co-infections in antiretroviral treatment naïve patients with HIV infection at a major treatment center in Ghana. J Med Virol., 84(1):6-10. 